\title{
CONFLICT RESOLUTION THROUGH EFFECTIVE COMMUNICATION
}

\author{
Binod Prasad Bista*
}

\begin{abstract}
Freedom of expression has surfaced in large parts of the world, particularly the newly independent nations and the countries that remained in isolation, along with the spread of democracies in those countries. With the rise of free expression of views often contesting with one another, conflicts of different kinds that were under suppression earlier, also emerged. Conflict in itself is considered neither good nor bad but it is judged by its outcome. Study of conflict, specifically the causes behind it relating to power struggle, economic competition, is important for achieving peace. One of the important tools for resolving conflicts is effective communication. Despite the stupendous advancement of information and communication technologies (ICTs), existence of digital divide has presented serious constraints in the application of available technologies. Potential of ICTs in conflict resolution is being increasingly recognized as it assists in promoting peace, preventing conflict through the use of early warning system. While the mobile technology generated SMS is credited for success of 'Arab Spring', considered as a non-violent method for regime change, there are also problems associated with it in fueling conflicts. It is, thus, necessary for communication, particularly media, to become transparent, reliable and ethical. Use of English language in doing business today cannot be overemphasized. Sometimes it requires more than language to resolve conflicts arising out of national interest related issues of the countries concerned. Sustainable peace demands intervention of a non-violent nature with consideration given to social justice and human rights. Effective communication in not merely an act of entering into dialogue and relaying views and perceptions to conflicting parties but also securing their trust and confidence in order to arrive at a mutually agreeable agreement for securing peace.
\end{abstract}

Key Words: Effective communication, conflict resolution language, digital divide.

Among several types of freedom promoted by the present day world, freedom of expression is the most valued right sought by people everywhere for a free, fair and just world. Freedoms of expression, freedom to assembly, and freedom to engage in an occupation of choice, 
among others, form an integral part of human rights. The Universal Declaration of Human Rights adopted by the United Nations General Assembly in the year 1948 in Paris, contains 30 Articles that are aimed at promoting and safeguarding freedom of speech and belief and freedom from fear and want-considered as the highest aspirations of the common people (United Nations, 1948). Two main factors, colonization of most developing countries and authoritarian regimes of remaining independent nations prevented free expressions of the people in the earlier years. With the advent of democratic system of governance in the post colonization period and independence of scores of countries after the end of the World War II, people have been enjoying greater freedom of expression. The end of the cold war further opened up and accelerated this process. The recorded data on conflicts for the past seventy years reveals that the level of conflicts during this period is decelerating. There have been 254 numbers of armed conflicts since 1946 (114 wars) and 144 numbers of armed conflicts since 1989 (47 wars) globally (Themner, L., 2014). However, the recorded data on conflicts being armed ones, also termed as violent conflicts, would be more complicated and intractable in nature, different from conflicts that can be resolved through the use of nonviolence and cultural understanding.

Conflict by itself is neither bad nor good. It outcome determines its nature to be either destructive or constructive. Thus, the efforts should be to minimize destructive outcomes, particularly resulting from violent conflicts, and maximize productive outcomes (Sandole, D. and Fisher, R., 2009).

Daniel Katz, one of the early theorists, focused on economic, value and power as three main sources of conflict (Kelman, H. and Katz, D., 1965). Not all conflicts belong to one specific type or in pure form but involve a mixture of sources. "Union-management conflict typically involves economic competition, but may also take the form of a power struggle and often involve different ideologies or political values" (Sandole, D. and Fisher, R., 2009). Levels of conflict generally take the form of intrapersonal (within) or interpersonal (outside) dimensions. Then there are role conflict, intergroup conflict, multiparty conflict and international conflict. Blake, Shepard and Mouton have identified three general strategies in dealing with conflicts: win-lose approach, lose-lose approach, and win-win approach. Another important source of conflict is traced to ineffective communication. "Miscommunication and misunderstanding can create conflict even when there are no 
incompatibilities" (Sandole, D. and Fisher, R., 2009). Lack of effective communication skill could result in confusion, further leading to conflict. Effective communication results in achieving the purpose for which it was designs. James Carey defines communication as "a symbolic process whereby reality is produced, maintained, repaired, and transformed" (Carey, I., 2009).

An important report produced by "Search for Common Ground" highlights new initiatives illustrating new developments and opportunities in communications. It states that governments, non-government, multilateral organizations and private sector are using several forms of communication, both old and new, for preventing conflict and promoting peace building in the post conflict period. However, there is very little evidence to support the claims. Nevertheless, the report acknowledges that though new tools of communication cannot provide full remedy for conflict prevention yet they present new channels of communication and new opportunities. Another important report by the United Nations in 2005 , points out to the basic problems faced by the global community due to the digital divide. Absence of necessary infrastructure, lack of access as well as inadequate regulatory frameworks in most developing countries, prevent the people there from using effective communication to conflict resolution. In addition, the technical issues such as data standards and interoperability of communication systems, and other issues of neutrality and impartiality need to be looked into (Stauffacher, D., 2005).

In spite of the inadequacies and challenges faced by most countries in using modern communication tools, Micheline Calmy-Rey is of the view that ICTs have helped in the establishment of early warning systems and coordination mechanisms. Julia Hoffman holds the view that Communication for Peace (C4P) provides cross-pollination and contributes to a more thorough engagement in important activities for peace. However, she finds it as a fragmented field of research requiring identification of major areas for further research agenda (Hoffman, J., 2013). Communication can be used to achieve peace through talks and negotiations although mass media and ICT are also equally useful. Media is seen as a double-edged sword that can either fuel violence through disinformation and intolerance or resolve conflicts by disseminating reliable, diverse views enabling society to make informed choices. A media run with personal ethics and access to diverse information can 
contribute to reconciliation and even alter misinformation (Cole, R., and Crawford, T., 2007).

Information and communication technology (ICT) can be used in six different ways such as providing information, processing information, improving decision making, reducing scarcity, supporting relationships and helping people understand each other. While internet increases information sharing, mobile technologies increase flow of information. "In particular the youngest generation is growing up in a world conditioned by mass media" (Yameogo, J., 2012). Supporting dissenting voice to America's war in Vietnam, Martin Luther King Junior said "A time comes when silence is betrayal" (King Jr. M., 1967). This statement also reflects the importance of communication in modern time. Harry S. Truman once said "When one American- who has done nothing wrong- is forced by fear to shut his mind and close his mouth- then all Americans are in peril" (Harry S. Truman, n.d.).

Understanding the importance and value of communication in conflict resolution is not enough. It has to be applied effectively to help people in conflict to live in peace and harmony. World Summit on the Information Society recognized the potential of ICT in promoting peace and preventing conflict including assisting peacekeeping missions as well as in the 'post-conflict peace building and reconstruction' (Tunis Commitment, 2005). Gordon Brown believes that the current groupings of ICTs have the power to prevent violence. Use of new ICTs, particularly social media such as the SMS and Face book contributed immensely to 'Arab Spring' for a non-violent change but at the same time use of ICTs, particularly the old media such as radio, caused tremendous harm in Rwanda. Post-election violence in Kenya reflects that SMS can be used to 'inflame ethnic tensions, spread hate speech and orchestrate violence'. 'Global Village' came into being because of modern information and communication technologies (McLuhan, M., 1965). Similar to the argument on conflict posited by Deutsch and Colemna, it becomes clearer that modern technology and its instruments are neither good nor bad but depend on the usage that one puts them to.

In spite of a surge in the development of ICTs strengthened by the tremendous power of globalization, there exist several limitations that cannot be put down. Cate Malek also pointed out to the limitations of citizen diplomacy where he sees a lot of merit including establishment of deep relationships and re-humanizing an enemy. There are distinct limitations present that prevent the use of ICTs such as vulnerability to 
outside environment, differences in power, and extensive resource requirement (Citizen Diplomacy, 2013). A global mapping exercise on communication for development efforts for UNICEF, taken as a social process that fosters dialogue and meaningful conversation for reducing the risk of a lapse into conflict, also generates transformation at all levels. By "promoting listening, building trust, appreciating differences, sharing knowledge and skills, and learning in order to lay foundations of a sustainable and durable peace" it is value laden. UNESCO is of the view that there would be a need to systematically fuse traditional media with modern communication media for getting the maximum benefits out of available communication.

The language of communication is as important, if not more, for any communication to be effective regardless of the technological sophistication and other instruments that support it. English language has been making inroads as the language for doing global business. At a new study of 1.6 million online test-takers in more than 50 countries, conducted by Education First, it is found that 'international sectors use English, and local sectors don't'; 'European countries speak great English, Asian countries are in the middle, and everyone else lags'; 'British Council reports that by 2020, two billion people will be studying English' (Forbes/Leadership, 2012). Kachru's Model of World Englishes (Karchu, B., 1992) shows the spread of English from inner circle (First language: US, UK, Canada, Australia, New Zealand) to Outer Circle (Bangladesh, Ghana, India, Kenya, Malaysia, Nigeria, Pakistan, Philippines, Singapore, Sri Lanka, Tanzania, Zambia) to expanding circle (China, Egypt, Indonesia, Israel, Japan, Korea, Nepal, Saudi Arabia, Taiwan, USSR, Zimbabwe). Jenny Gilsdorf in her concluding remarks states:

worldwide use of English for business is an accident of history, not a superiority of language, and that history moves on. Internet use of Mandarin, Hindi, and Spanish is rising (Wells and Teather, 2000). If regional trading blocks increase in number and in influence. English could become irrelevant within some of the blocks (Graddol, 1997). Or if translation software becomes a lot better than it is at present, we might see business people needing a common language less" (Gilsdorf. J., 2002).

Karchu Model of World Englishes (1985) appropriately reflects Nepal's position along with China, Indonesia, Japan, and Republic of Korea in Asia in the expanding circle today as Nepal had remained in isolation for nearly two hundred years of its existence for protecting and preserving its independence. Except for the formal education system established in Colleges and Universities in the UK mode, English as a language was made compulsory and a medium of teaching in higher education by the Tribhuvan University. 
Although a part of the population pursuing higher education got the benefit of English language, majority population has a long way to go. However, this process is accelerating as a result of e-commerce and e-business that is sweeping the world. Nepal has distinguished herself as an effective peacekeeper in the service of the United Nations and is engaged in several conflicting parts of this world. This activity has also helped in the promotion of the English language besides the national policy of foreign employment first introduced in the early 1990s.

While Nepal does not require the English language to resolve internal conflicts within the nation but it is necessary for interaction in several fields such as understanding the essence of development cooperation, resolving human rights issues, protecting labor rights. Nepal has become a party to several international treaties, conventions and agreements that require it to fulfill its duties and obligations agreed in those treaties. The recent examination of Nepal's human rights situation by the Human Rights Council Universal Periodic Review (UPR) Working Group in Geneva and the interactions therein reflects Nepal's position on those issues. The review, based on a national report of the government; information obtained from independent human rights experts and groups; and information provided by stakeholders that include national human rights Institutions, regional organizations and civil society groups, demands that Nepal met all its obligations that it has undertaken while acceding to the international convention on human rights and its protocols (The Himalayan Times, 2015). Nepal has to deal with all reports and comments prepared by the UN agencies or submitted to the UN and make appropriate responses as well as prepare proper documentation in the English language. This task is as important for Nepal as engaging in international trade and business.

However, language becomes ineffective when the disagreement between two nations is rooted in securing national interest of the countries concerned as can be seen from the current impasse between Nepal and India. Language is no barrier in the conduct of Nepal-India relations as people from both sides of the border speak a variety of languages common to both. Despite this reality there seems to be a serious aberration in Indo-Nepal ties, which the Ambassador of India to Nepal says is temporary. The Indian Ambassador asserts that "The normal supplies of goods and commodities from India have been disrupted and the main reason for this interruption is the disturbance at some of the border check posts, one of the most significant 
ones being Birgunj/Raxaul" (Rae, R., (2015, November 9). At the same time Nepalese Ambassador to India feels that he has been kept in dark until at the last moment on the ensuing issues of disagreements by India and the counters allegations made by the Indian side such as denial of citizenship to the Madhesis and Tharus groups, and Nepal's present constitution has followed internationally accepted practice for holding top posts of the country, and it is Nepal's internal matter. He added further "Nepal and India are linked heart to heart" (Upadhyaya, D., 2015, November 6). Whatever the real issue, it is a reality that the people of Nepal are pushed to the edge of catastrophic disaster by the present action.

Nepal is calling it a 'blockade' clamped down by India but India is taking a stand that there is no 'blockade' and the current situation has resulted from violent protests mounted by the Madheshi parties in the border towns of Nepal. However, governments of both nations appear to be open for dialogue. The importance of dialogue in the present context of India-Nepal relations cannot be overemphasized despite the fact that people of Nepal arte suffering and hurting as a result of disruption of supply of fuel as well as commodities of daily necessity. It is a wellknown fact that confrontations and conflicts, particularly between contiguous neighbors, are detrimental not only to the long-standing friendly relations but also for the people living on both sides of the border.

Ever since the end of Second World War the international community is laying stress on pacific resolution of conflicts, be they domestic, regional or international. Barring few exceptions most experts believe that the world today is much safer than it was during the period of cold war. One of the founding fathers of peace research today, John Galtung, drew a conclusion that reduction in violence can be achieved by: removing barriers in space; organization of knowledge; in time and constructive studies (Galtung, J., 1985). Hans Koehler holds the view that a new culture of tolerance is required to overcome the new threat of aggressive intolerance (Chler, H., 1995). Harman and Markley emphasize that "Peace involves non-violent strategies to resolve conflict; it involves constructive approach to social injustice and human rights; it involves in the end taking care of the earth and its life-support processes" (Harman, W. and Markley, O., (eds.), 1984). The United Nations Security Council issued a statement in 1992 which recognized that non-military sources of instability in the economic, social, humanitarian and ecological fields have become threats to peace and security, and in response to it 'Agenda for 
Peace' was created by the UN under the leadership of the Secretary General Boutros Boutros Ghali (Ghali, B., 1995).

Sustainable peace cannot be achieved without knowing conflicts. It calls for a study and understanding of individual culture, culture of societies, national culture and between nations at the regional and global levels. Cultural dynamism makes the matter more complicated and difficult to fathom by one society thus requiring the support of all stakeholders. Although the idea is to achieve peace ultimately but the focus has been provided by many including Johan Galtung on conflict as peace and conflict are considered to be the two sides of the same coin. Any peaceful resolution of a conflict demands that the interveners, mediators or conflict resolution experts use extreme care and caution in dealing with the conflicting parties. The purpose of involvement of peace experts is to contain the conflict in the first place, prevent it from escalation to violence and slip into a stage of intractability, but make sincere efforts to achieve lasting peace. This exercise can only be carried out if the interveners have full understanding of the nature and type of conflict and they are competent to communicate with the parties in conflict. Effective communication is not simply entering into dialogue and relaying views and perceptions to conflicting parties but securing trust and confidence of involved parties in order to arrive at a mutually acceptable agreement with a view to achieving lasting peace.

\section{WORKS CITED}

Hoffman, J. (2013). Conceptualizing Communication for Peace (Occasional Working Papers ed., Vol. No. 1). San Hose: University for Peace.

Casrey, J. (2009). A Cultural Approach to Communication. In Search for Common Ground. New York: Routledge.

Chlere, H. (1985). The New International Information and Communication Order: Basis for Cultural Dialogue and Peaceful Coexistence among Nations. Wien: W. Braumuller.

Citizen Diplomacy (2013). In CRInfo Project. Boulder, Colorado: University of Colorado.

Cole, R., and Crawford, T. (2007, June 1). Idealware Helping Nonprofits Make Smart Software Decisions. Retrived November 18, 2015, from http://www.idealware.org/articles/peace through_ICTs.php.

Communications for Peace Building (UN Systemwide Special Initiative on Arica ed., Vol. Component 1C) (1998). Paris: UNESCO. 
Deutsch, M. (2000). The Handbook of Conflict Resolution: Theory and Practice. San Francisco: Jossey-Bass.

English-- The Language of Global Business (2012). Forbes/Leadership.

Galtung, J. (1985). Twenty-Five Years of Peace Research: Ten Challenges and some Responses. Journal of Peace Research, 141-158.

Ghali, B. (1995). An Agenda for Peace, 1995 (2nd ed.). New York: United Nations.

Gilsdorf, J. (2992). Standard Englishes and World Englishes: Living with a Polymorf Business Language. International Journal of Business Communication, 39(No.3), 364-378, doi: 2002.

Global Mapping of Communication for Development Interventions in Peace Building and Conflict (2013). New York, N.Y., New York: UNICEF.

Harman, W., and Markley, O. (eds.) (1984). Changing Images of Man. Stanford Institute International.

Harry S. Truman (n.d.). Brain Quote.com.Retrieved November 18, 2015, from Brainy Quote.com Web site: http://www.brainyquote. com/quotes/authors/h/harry_s_truman.html.

Karchu, B. (1992). The Other Tongue. In Teaching World Englishes (2nd ed., pp. 355-365). Illinois: University of Illinois.

Kelman, H., and Katz, D. (1965). Nationalism and Strategies of International Conflict Resolution. In International behavior. A Socialpsychological Analysis. Edited by Herbert C. Kelman. (By various authors.), pp. xiv. 626. Holt, Rinehart and Winston: New York.

King Jr., M. (1967, April 4). Lecture Presented at Meeting of Clergy and Laity in Riverside Church, New York, N.Y.

McLuhan, M. (Writer) (1965, January 1). Take 30 Program (Television Broadcast). New York, N.Y.: CBC TV.

Nepal UPR kicks off in Geneva, DPM Thapa presents reports on (2015, November 4). The Himalayan Times.

Rae, R. (2015, November 9). India Noted Constitution Means it's a Major Development. The Kathmandu Post, p. 7.

Sandole, D., and Fisher, R. (2009). Interactive Conflict Resolution. In Handbook of Conflict Analysis and Resolution. London: Routledge.

Stauffacher, D. (2005). Foreword. In Information and Communication Technology for Peace the Role of ICT in Preventing, Responding to and Recovering from Conflict. New York, N.Y.: United Nations ICT Task Force. 
Stauffacher, D. (2005). Information and Communication Technology for Peace the Role of ICT in Preventing, Responding to and Recovering from Conflict. New York, N.Y.: United Nations ICT Task Force.

The Universal Declaration of Human Rights, United Nations (1948). Retrieved November 18, 2015, from http://www.un.org/en/universal/declaration-humanrights/index.html.

Themner, L., and Wallensteen, P. (2014). Armed Conflicts, 1946-2013. Journal of Peace Research, 541-554.

Tunis Commitment (2005, November 18). Retrived November 18, 2015 from http://www.itu.int/net/wsis/docs2/tunis/off/7.html.

Upadhyay, D. (2015). China's Influence is Impossible. New Spotlight, 09(0), 13-13.doi:06-26.11.2015.

Yameogo, J. (2012, July 27). The Role of Media in Peace Building Conceits Resolution and Good Governance. Lecture presented at Workshop in Kenya, Mombasa. 